\title{
Modified Caldwell-Luc Technique to retrieval of tooth fragment displaced into the maxillary sinus: A case report
}

Técnica de Caldwell-Luc modifficada para remoção de fragmento dentário do seio maxilar: Relato

de caso

Técnica de Caldwell-Luc modificada para recuperación de fragmeno dental del seno maxilar: Reporte de un caso

José Wittor de Macêdo Santos

ORCID: https://orcid.org/0000-0002-2584-2381 Federal University of Rio Grande do Norte, Brazil E-mail: josewittor@hotmail.com

Emily Ricelly da Silva Oliveira

ORCID: https://orcid.org/0000-0002-0920-8129 Federal University of Rio Grande do Norte, Brazil E-mail: oliveiraemily@ outlook.com

Humberto Pereira Chaves Neto ORCID: https://orcid.org/0000-0002-7556-536X Federal University of Rio Grande do Norte, Brazil E-mail: humbertopchaves@gmail.com

Fernanda Soares Ramos ORCID: https://orcid.org/0000-0002-9877-456X Federal University of Rio Grande do Norte, Brazil E-mail: fernandasoares098@gmail.com

Braz da Fonseca Neto

ORCID: https://orcid.org/0000-0002-4338-7925 Federal University of Rio Grande do Norte, Brazil E-mail: brazneto2511@gmail.com

Edynelson da Silva Gomes

ORCID: https://orcid.org/0000-0001-9358-3011 Federal University of Rio Grande do Norte, Brazil E-mail: edymaserati@hotmail.com

Adriano Rocha Germano ORCID: https://orcid.org/0000-0002-1661-8038 Federal University of Rio Grande do Norte, Brazil

E-mail: adrianogermanoufrn@yahoo.com.br

\begin{abstract}
During the surgical removal of maxillary molars, tooth or fragment displacement into the maxillary sinus may occur. The presence of foreign bodies inside these cavities leads to complications such as mucoceles, cellulitis, oroantral fistulae and maxillary sinusitis, to prevent the arise and worsening of complications, these events must be addressed in an early stage. This article aims to report the removal of a tooth root from the maxillary sinus, through the modified Caldwell-Luc (CLM) approach and describe the current indications for the Caldwell Luc technique. It reports an upper third molar surgery in which a patient had the distal root of the left superior third molar displaced into the maxillary sinus, later showing signs of sinus opacification and loss of patency of the maxillary ostium obstructed by the root. After antibiotic treatment, the root was recovered through the CLM technique by local anesthesia, without complications. Foreign bodies in the maxillary sinuses must be urgently addressed, avoiding the development of infectious conditions, the CLM approach is the choice approach to manage these complications by a simple and safe way.
\end{abstract}

Keywords: Maxillary sinus; Third molar; Maxillary sinusitis; Maxillofacial surgery.

\section{Resumo}

Durante exodontias de molares superiores, deslocamentos de dentes ou fragmentos podem ocorrer para dentro dos seios maxilares. A presença de corpos estranhos no interior destas cavidades pode levar a complicações como mucoceles, celulites, fístulas oro-antrais e sinusite maxilar, desta forma, devem ser removidos precocemente, para evitar surgimento e agravamento de complicações. Este trabalho tem o objetivo de relatar um caso de remoção de raiz dentária do seio maxilar, por meio da técnica de Caldwell-Luc modificada (CLM) e descrever as correntes indicações 
para esta abordagem. Trata-se de um paciente submetido a cirurgia de terceiros molares, tendo a raiz distal do terceiro molar superior esquerdo deslocada para o interior do seio maxilar, apresentando opacificação do seio e oclusão do óstio do seio pela raiz. Após antibioticoterapia, a remoção da raiz foi realizada sob anestesia local por meio da técnica de CLM, sem complicações. Corpos estranhos nos seios maxilares devem ser prontamente manejados, evitando o surgimento de quadros infecciosos, o acesso de CLM demonstra-se como a abordagem de escolha para lidar com essas complicações de maneira simples e segura.

Palavras-chave: Seio maxilar; Terceiro molar; Sinusite maxilar; Cirurgia maxilofacial.

\section{Resumen}

Mientras la extracción de los molares superiores, pueden producirse desplazamientos de los dientes o fragmentos hacia los senos maxilares. La presencia de cuerpos extraños en el interior de estas cavidades puede derivar en complicaciones como mucoceles, celulitis, fístulas oroantrales y sinusitis maxilar, por lo que deben ser removidas precozmente, para evitar la aparición y agravamiento de complicaciones. Este trabajo tiene como objetivo reportar un caso de extracción de la raíz del diente del seno maxilar, utilizando la técnica de Caldwell-Luc modificada (CLM) y describir las indicaciones actuales para este abordaje. Se trata de un paciente intervenido de tercer molar, con la raíz distal del tercer molar superior izquierdo desplazada hacia el seno maxilar, presentando opacificación del seno y oclusión del ostium del seno por la raíz. Tras la antibioterapia se realizó la extracción radicular bajo anestesia local mediante técnica CLM, sin complicaciones. Los cuerpos extraños en los senos maxilares deben ser manejados con prontitud, evitando la aparición de condiciones infecciosas, el acceso a CLM se muestra como el abordaje de elección para afrontar estas complicaciones de forma sencilla y segura.

Palabras clave: Seno maxilar; Tercer Molar; Sinusitis maxilar; Cirurgía bucal.

\section{Introduction}

Dental extractions are the most common surgical procedures in dental practice, dentists must be properly prepared to deal with its risks and complications. During the removal of maxillary molars, accidental displacement of teeth or dental fragments can occur to a variety of surrounding spaces, what may be associated with diagnostic error, inadequate imaging methods, misuse of surgical instruments, lack of mastery of the surgical technique or local anatomical features (Sencimen et al., 2016; Bozkurt \& Edem, 2017).

Among the possible sites of displacement of teeth or dental fragments, the maxillary sinus is the most common. Although small fragments may remain asymptomatic, removal is recommended, as even after long asymptomatic periods, complications such as oroantral fistulaes, mucoceles, cellulitis or, more commonly, maxillary sinusitis, which can affect $48 \%$ to $73 \%$ of patients, may arise (Hara et al., 2018; Manor et al., 2018; Gnigou et al., 2019).

Treatment choices are influenced by the presence and degree of sinus inflammation, size, location and positioning of the dental fragment, which is best evaluated by computed tomography (Huang et al., 2011; Hara et al., 2018). The literature describes the alveolar approach and the Caldwell-Luc (CL) surgery as being the two main techniques for retrieving dental roots from the maxillary sinus, however a retrieval attempt through the extraction socket can enlarge the oroantral communication, potentially causing an oroantral fistulae, and is related to low success rate (Huang et al., 2011).

The CL technique was the main surgical procedure to treat pathologies and remove foreign bodies from the maxillary sinus until the development of endoscopic surgery, which offers the possibility of a minimally invasive procedure, however, when it comes to foreign bodies of large dimensions, such as roots, teeth and implants, minimally invasive access becomes inadequate, in addition, it needs to be performed under general anesthesia or sedation, increasing its costs and morbidity (Furuya et al., 2015; Hara et al., 2018). Huang et al. (2011) described a CLM approach, performed under a more conservative access and narrower bone window, without removal of the healthy mucosa or inferior meatal antrostomy, decreasing the surgical time and risk of complications, providing greater predictability and postoperative comfort. This article aims to describe the use of CLM technique to remove a dental fragment accidentally displaced into the maxillary sinus, during an attempt to remove an impacted upper third molar. 


\section{Methodology}

This article is a case report, descriptive and qualitative. According to Pereira et al., (2018) a case report refers to a description of a specific subject, detailing it in a way that highlights its nuances and qualify its relevance. This article details the case of a patient who underwent removal of a tooth fragment displaced to the maxillary sinus by the CLM technique. Regarding ethical aspects, the patient was provided an Informed Consent Form (ICF) and authorized the procedure and its publishing by signing the document.

\section{Case report}

A 29-year-old male, ASA I, attended the service of Oral and Maxillofacial Surgery at the Federal University of Rio Grande do Norte, to undergo a surgical procedure of removal of third molars (TMs). The extraction of all four TMs was planned under local anesthesia. The preoperative panoramic radiograph, despite the lack of details due to the overlapping of anatomical structures, showed that the upper left third molar (TM) was in close contact with the neighboring tooth and with the maxillary sinus (Figure 1).

Figure 1. Preoperative panoramic radiograph.

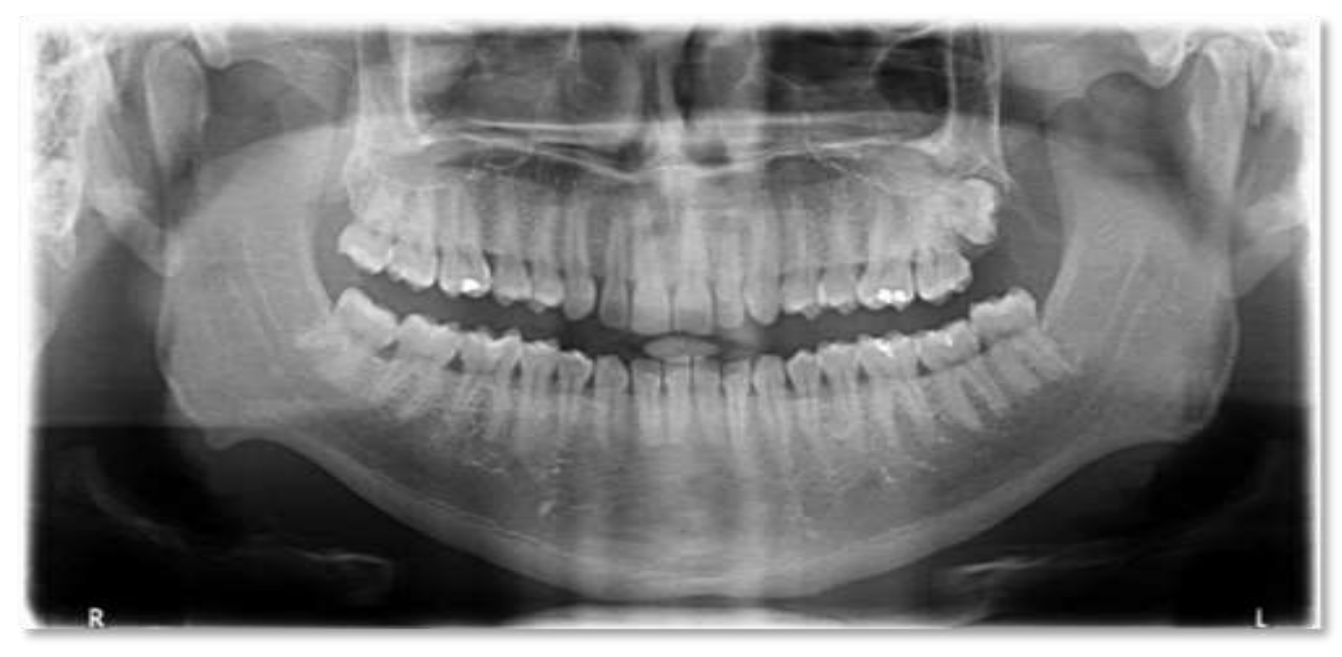

Preoperative radiograph showing the right and left lower TMs totally erupted, class IA of Pell \& Gregory (Pell \& Gregory, 1933). Upper left TM fully impacted (Position C), its roots near with the neighboring tooth and maxillary sinus. Source: Authors.

The removal of the upper and lower right TMs was performed under local anesthesia without complications, the extractions on the left side were scheduled for a next appointment. The second surgical procedure was also carried in an ambulatory facility, beginning with the extraction of the upper left TM, under local anesthesia of the left posterior superior alveolar nerve, left greater palatine nerve and anesthetic infiltration around the incision area to promote hemostasis. A mucoperiosteal flap was design and a releasing incision at the level of the second molar was made. The flap was reflected to expose the crown of the TM, an ostectomy was performed around the tooth followed by an unsuccessful attempt of luxation. Sectioning of both crown and roots (the later in close contact with the roots of the second molar) was performed, the crown and mesial root were successfully removed. During the attempt to remove the distal root, it went out of sight, being hypothesized that it could have moved into left maxillary sinus. Recovery through the extraction socket was not attempted, it was decided to end the procedure performing a tight suture and request radiographic and tomographic exams to locate the dental fragment so it could be safely removed. 
The panoramic radiograph confirmed the displacement of the distal root into the maxillary sinus, being positioned in its posterosuperior region (Figure 2). Three days after the extraction attempt, the patient underwent a multislice computed tomography scan (CT) to investigate the exact size and position of the dental fragment, as well as maxillary sinus health. The tomography showed that the dental fragment had moved inside the sinus and placed itself in the superomedial aspect of the cavity, at the level of the maxillary ostium, and veiling of the left maxillary sinus (Figure 3). Antibiotic therapy with Amoxicillin/Clavulanate Potassium $875 \mathrm{mg}$-125mg was prescribed for 14 days, followed by a new procedure to remove the dental fragment.

Figure 2. Panoramic radiograph after first attempt of extraction.

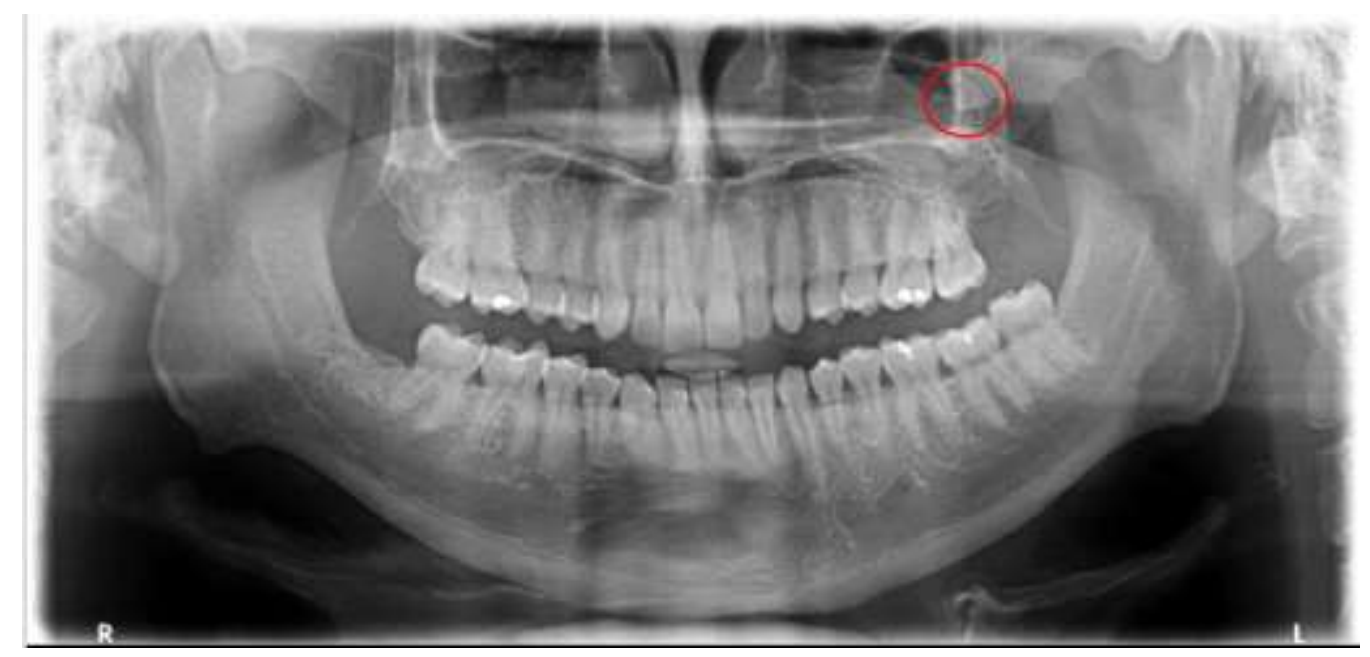

Panoramic radiograph after the first attempt of extraction showing the distal root of the upper left TM displaced into the maxillary sinus (red circle). Source: Authors. 
Figure 3. CT scan showing the axial (A) and coronal (B) images of the displaced root.

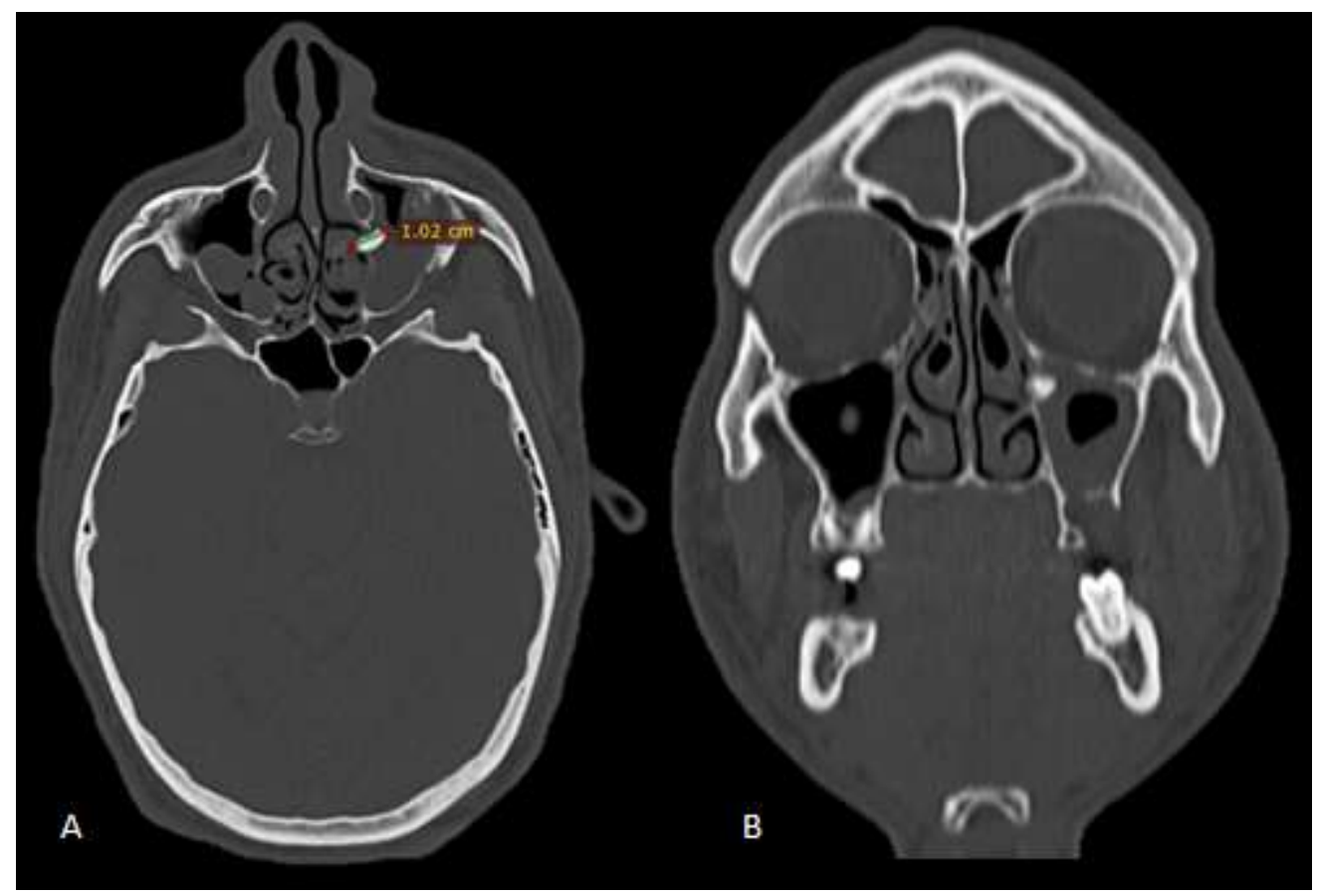

(A) The axial slice shows a tooth fragment measuring $1.02 \mathrm{~cm}$ in its long axis, displaced in the region of the maxillary ostium with proximity to the nasolacrimal duct. (B) The coronal slice shows the root positioned on the medial sinus wall near the orbital floor, as well as the exact area of the oroantral communication through which the root was displaced. Source: Authors

\subsection{Removal of dental fragment through CLM technique}

The patient underwent 14 days of antibiotic treatment before the retrieval surgery, which was performed in an ambulatory facility. At the beginning of the procedure, the patient was placed in supine position to allow the root to move into the narrower posterior region of the sinus, anesthetic block of the left posterior superior alveolar nerve, infraorbital nerve, and anesthetic infiltration around the incision area, to promote hemostasis, was performed. A linear incision through the maxillary vestibular mucoperiosteum, $2 \mathrm{~mm}$ above the mucogingival junction, around $2.5 \mathrm{~cm}$ in length, extending from the distal region of the upper left canine to the upper left first molar, was executed. The incision was design so that it could rest on healthy bone, decreasing the possibility of dehiscence of the wound. After flap reflection and exposure of the canine fossa, an area between the nasomaxillary and zygomaticomaxillary buttresses was delimited with a fissure bur, where a bone window of $\sim 5$ mm was opened on the anterior wall of the maxillary sinus (Figure 4). 
Figure 4. Incision and bone window to access the maxillary sinus.

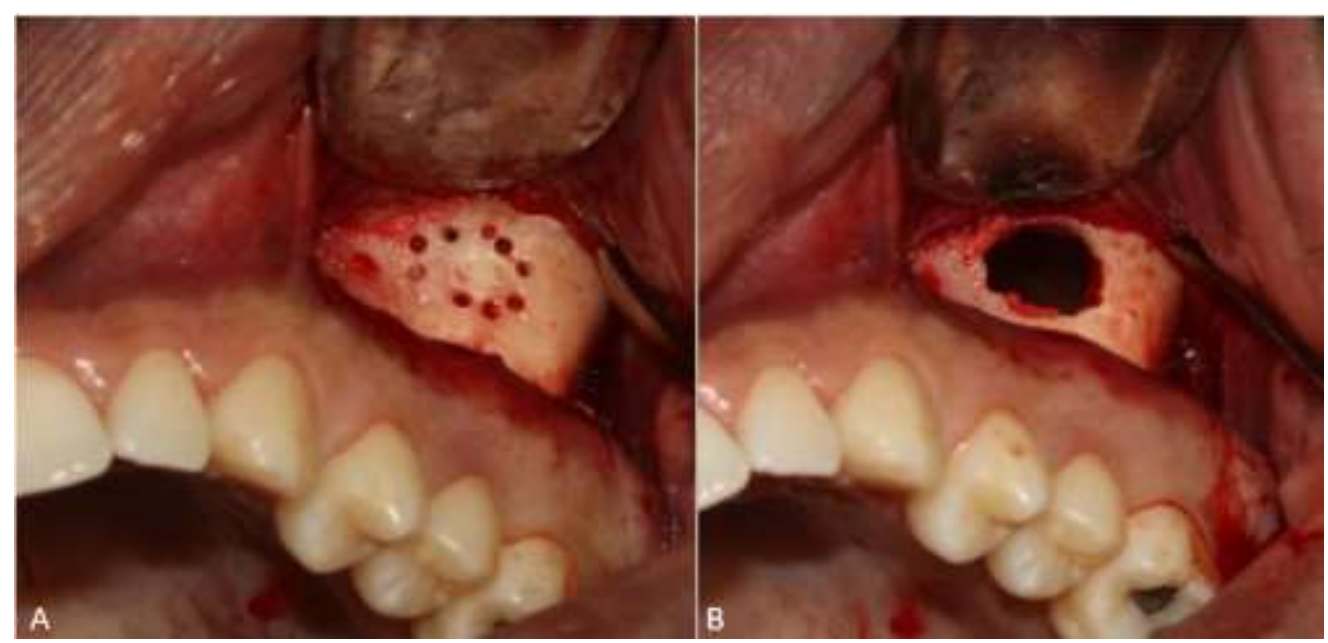

(A/B) Incision and delimitation of the bone window area in the region of the canine fossa to access the maxillary sinus. Source: Authors

An initial attempt was made to retrieve the dental fragment with the suction cannula, without success. The cavity was copiously irrigated with saline solution, the irrigation was then directed to the medial wall of sinus and orbital floor, following a new attempt to capture the fragment by suction. The fragment was successfully removed without complication, being retrieved in a total surgical time of 25 minutes (Figure 5). The flap was repositioned and sutured by continuous scalloped sutures, which was removed 7 days later. The patient improved uneventfully in both immediate and late postoperative evaluation. The 1 year and 5 months postoperative follow-up showed no signs of sinus pathology, oroantral fistulae or other complications (Figure 6).

Figure 5. Retrieval of dental fragment with a suction cannula.

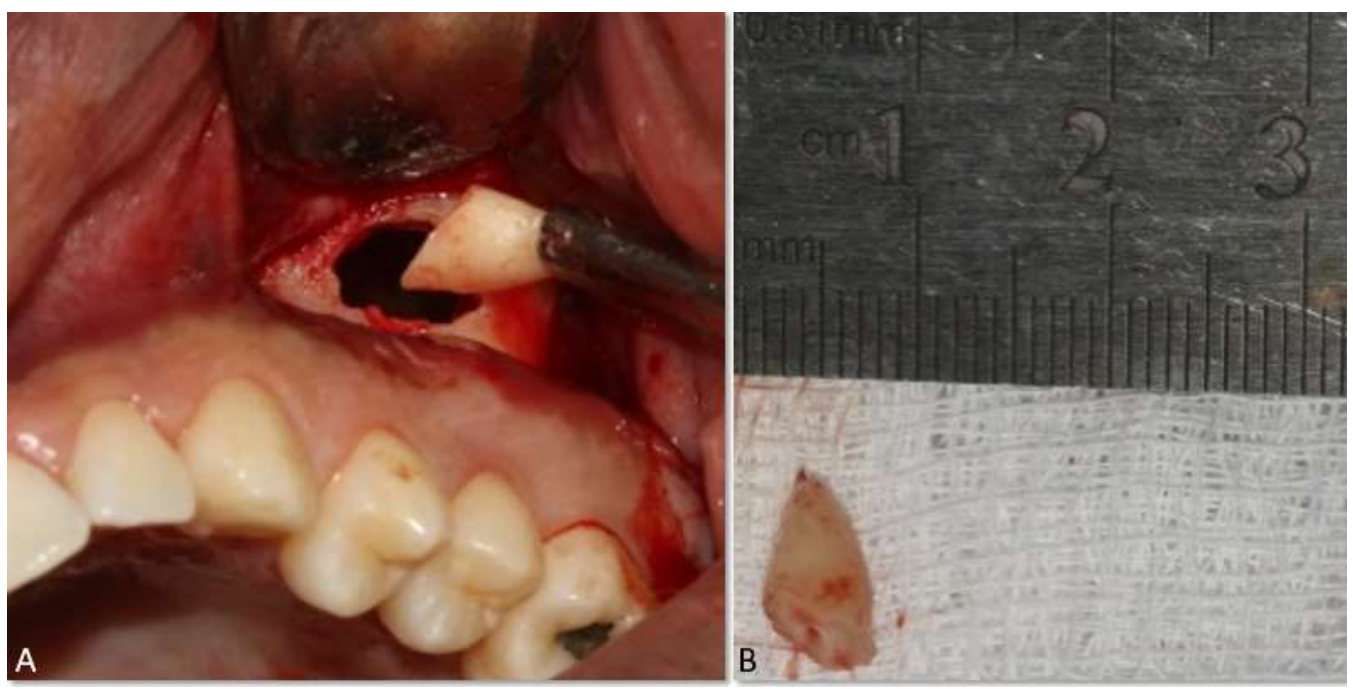

(A) Root retrieval with the suction cannula after copious irrigation of the maxillary sinus. (B) Aspect of the tooth root after retrieval. Source: Authors 
Figure 6. Panoramic radiograph after removal of the dental fragment.

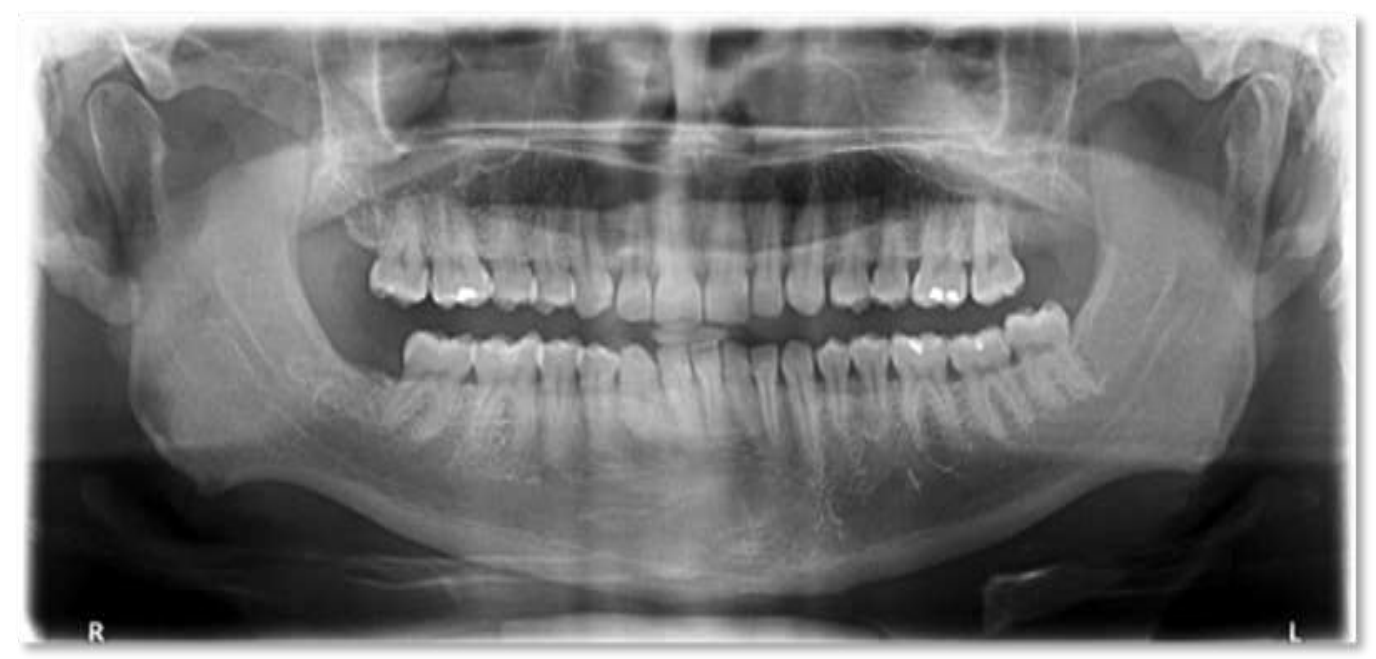

Postoperative panoramic radiograph showing a healthy left sinus, similar to the contralateral sinus. Source: Authors

\section{Discussion}

Teeth or dental fragments can be displaced into the maxillary sinus during extractions, among the reasons for this incident are inappropriate use of instruments, improper choice of technique or inexperience of the surgeon. The presence of foreign bodies may result in chronic maxillary sinusitis, purulent exudate, oedema, facial asymmetry, localized pain and headache, amongst other symptoms, which can evolve to more severe conditions such as cellulitis. Once foreign bodies have been moved into the sinus, these events should be addressed early to avoid severe complications. Evaluation of imaging exams, especially CT, is essential for a precise diagnose and choice of proper surgical approach (Sencimen et al., 2016; Bozkurt \& Erdem, 2017; Asmael, 2018; Hara et al., 2018; Manor et al., 2018; Gnigou et al., 2019; Courtot et al., 2020).

The CL surgery is well-established in scientific literature, before the development of endoscope surgery, CL procedure was the technique of choice to treat pathologies of the maxillary sinus, in addition to retrieval of foreign bodies. Endoscopic surgery combined with antibiotic therapy is currently the most conservative technique for managing the maxillary sinus, however, the cost of equipment, need of surgical training and impossibility of performing the technique under local anesthesia are still barriers to its broad use, furthermore, the endoscope is not suitable for retrieval of all types of foreign bodies. The CL technique remains an effective and safe option for a variety of cystic, odontogenic, and neoplastic lesions within the maxillary sinus, as well as for sinusitis that have not responded to antibiotic therapy and minimally invasive approach, offering the advantage of ample and direct access to the interior of the cavity (Huang et al., 2012; Furuya et al., 2015; Chagas Junior et al., 2016; Aukštakalnis et al., 2018).

The CL technique was first described as a two-step surgical procedure. First, wide access to the maxillary sinus through the canine fossa, by an average bone window of $2.5 \mathrm{~cm}$, followed by removal of the pathological sinus mucosa and inferior meatal antrostomy to create a wider opening in the ostium region, to allow passive sinus drainage. However, the evidence of benefits for performing antrostomy of the inferior meatus proved to be controversial, in addition, there is a risk of damage to the nasolacrimal duct, possibility of early closure of the opening, and mild to severe epistaxis, therefore, this procedure is considered ineffective and has currently lost its validity (Şahin et al., 2020).

Huang \& Chen (2012) introduced a series of 50 cases in which CLM technique was successfully performed without inferior antrostomy. Nevertheless, the incisions, flap detachment and bone window were similar to the original operation; at the end, the sinus was packed with iodoform gauze impregnated with bacitracin-neomycin ointment for 5 days, for initial 
hemostasis and topical antibiotic therapy, requiring a second procedure to remove the packing followed by a new placement of sutures, thus, this technique still offered significant morbidity, which had to be taken under consideration when choosing the best approach to simpler cases, such as retrieval of teeth and small foreign bodies from the maxillary sinuses.

Another version of the CL technique was proposed by Huang et al. (2011), eliminating the need for inferior meatus antrostomy and stripping of sinus healthy mucosa, establishing a more conservative access and narrower bone window, that could be performed under local anesthesia. This technique is currently the method of choice for retrieval of teeth, dental fragments, implants, and small foreign bodies from the maxillary sinus. It is a simple surgical procedure with reduced rate of complications when compared to the original CL technique and other approaches.

Huang et al. (2011) also introduced a classification for different types of dental fragments displaced into the sinus. The mobile type: a root that may change position between imaging exams when the patient shakes its head or even during daily activities; fixed type A: non-mobile root located between sinus membrane and bone; fixed type B: root into the sinus cavity, however, adhered to the sinus membrane. Each of these types requires specific identification and surgical approach. The fragment reported in this article corresponds to the mobile type, which is considered the easiest to remove.

Currently, indications for the CL technique include removal of cysts and tumors, extensive osteonecrosis, removal of large foreign bodies, sinusitis that requires total stripping of the mucosa, mycotic infections of the maxillary sinus, facial trauma, and management of certain types of epistaxis. Complications associated with the classic technique are swelling, pain that may range from mild to severe, transoperative and postoperative hemorrhage, devitalization of teeth and, more rarely, paresthesia of the infraorbital region and epiphora, when the lacrimal drainage system is damaged (Huang et al., 2012; Jeong et al., 2016; Asmael, 2018). Nonetheless, part of the complications attributed to the procedure may occur due to inexperience and unprecise methods during the surgery. Careful access to the maxillary sinus and surrounding structures, along with protection to the infraorbital nerve, are crucial steps to minimize the morbidity of the technique.

\section{Conclusion}

The presence of foreign bodies inside the maxillary sinus can lead to a series of complications, the most common of which is maxillary sinusitis. The displacement of teeth or dental fragments into the sinus, although rare, may occur during extraction of maxillary molars, these incidents should be addressed as soon as possible. The CLM technique is a simple, fast, and effective way to retrieve dental fragments displaced into the maxillary sinuses, offering the possibility of being performed in an ambulatorial facility under local anesthesia, with minimal risk, low costs and low complication rates, when performed by dentists with good training in oral surgery.

\section{References}

Asmael, H. M. (2018). The Modified Caldwell-Luc Approach in Retrieval of Accidentally Displaced Root into the Maxillary Sinus. Journal of Craniofacial Surgery, 29(2), 130-131.

Aukštakalnis, R., Simonavičiūte, R., \& Simuntis, R. (2018). Treatment options for odontogenic maxillary sinusitis: a review. Stomatologija, Baltic Dental and Maxillofacial Journal 20(1), 22-26.

Bozkurt, P., \& Erdem, E. (2017). Management of upper and lower molars that are displaced into the neighbouring spaces. British Journal of Oral and Maxillofacial Surgery, 55(9), 49-52.

Chagas Junior, O. L., Moura, L. B., Sonego, C. L., Farias, E. O. C., Giongo, C. C., \& Fonseca, A. A. R. (2016). Unusual Case of Sinusitis Related to Ectopic Teeth in the Maxillary Sinus Roof/Orbital Floor: A Report. Craniomaxillofacial Trauma \& Reconstruction, 9(3), $260-263$.

Courtot, R., Devoize, L., Louvrier, A., Pereira, B., Caillet, J., Meyer, C., Barthélémy, I., \& Depeyre, A. (2020). Surgical approach of ectopic maxillary third molar avulsion: Systematic review and meta-analysis. Journal of Stomatology, Oral and Maxillofacial Surgery, 1-6.

Furuya, Y., Norizuki, Y., \& Yajima, Y. (2015). A Case of Simultaneous Ectopic Tooth Extraction and Removal of Migrated Dental Implant from Maxillary Sinus. The Bulletin of Tokyo Dental College, 56(4), 253-258. 
Research, Society and Development, v. 10, n. 2, e26210212353, 2021

(CC BY 4.0) | ISSN 2525-3409 | DOI: http://dx.doi.org/10.33448/rsd-v10i2.12353

Gnigou, M., Goutzanis, L., Sarivalasis, S., \& Petsinis, V. (2019). Retrieval of displaced implants inside the maxillary sinus: two case reports and a short review. International Journal of Implant Dentistry, 5(1), 1-8.

Hara, Y., Shiratsuchi, H., Tamagawa, T., Koshi, R., Miya, C., Nagasaki, M., Ohyama, T., Oka, S., Sakashita, H., Kaneko, T. (2018). A large-scale study of treatment methods for foreign bodies in the maxillary sinus. Journal of Oral Science, 60(3), 321-328.

Huang, I. Y., Chen, C. M., \& Chuang, F. H. (2011). Caldwell-Luc procedure for retrieval of displaced root in the maxillary sinus. Oral Surgery, Oral Medicine, Oral Pathology, Oral Radiology, and Endodontology, 112(6), 59-63.

Huang, Y. C., \& Chen, W. H. (2012). Caldwell-Luc Operation Without Inferior Meatal Antrostomy: A Retrospective Study of 50 Cases. Journal of Oral and Maxillofacial Surgery, 70(9), 2080-2084.

Jeong, K. I., Kim, S. G., Oh, J. S., \& You, J. S. (2016). Implants Displaced Into the Maxillary Sinus. Implant Dentistry, 25(4), 547-551.

Manor, Y., Anavi, Y., Gershonovitch, R., Lorean, A., \& Mijiritsky, E. (2018). Complications and Management of Implants Migrated into the Maxillary Sinus. The International Journal of Periodontics \& Restorative Dentistry, 38(6), e112-e118.

Pell, G. J., \& Gregory, B. T. (1933). Impacted mandibular third molars, classification and modified technique for removal. Dental Digest, 39, $330-338$.

Pereira, A. S., Shitsuka, D. M., Pereira, F. J., \& Shitsuka, R. (2018). Metodologia da pesquisa científica UFSM. https://repositorio.ufsm.br/bitstream/handle/1/15824/Lic_Computacao_Metodologia-Pesquisa-Cientifica.pdf?sequence=1

Şahin, M. M., Yılmaz, M., Karamert, R., Cebeci, S., Uzunoğlu, E., Düzlü, M., \& Ceylan, A. (2020). Evaluation of Caldwell-Luc Operation in the Endoscopic Era: Experience From Past 7 Years. Journal of Oral and Maxillofacial Surgery, 78(9), 1478-1483.

Sencimen, M., Gülses, A., Secer, S., Zerener, T., \& Özarslantürk, S. (2016). Delayed retrieval of a displaced maxillary third molar from infratemporal space via trans-sinusoidal approach: a case report and the review of the literature. Oral and Maxillofacial Surgery, 21(1), 1-6. 